\title{
Soil organic matter as affected by management systems, phosphate fertilization, and cover crops
}

\author{
Géssica Pereira de Souza(1), Cícero Célio de Figueiredo(2) and Djalma Martinhão Gomes de Sousa(1)
}

\begin{abstract}
(1)Embrapa Cerrados, BR 020, Km 18, Caixa Postal 08223, Planaltina, CEP 73310-970 Brasília, DF, Brazil. E-mail: gessicapsouza@gmail.com, djalma.sousa@embrapa.br (2)Universidade de Brasília, Faculdade de Agronomia e Medicina Veterinária, Campus Universitário Darcy Ribeiro, Instituto Central de Ciências, Ala Sul, Caixa Postal 04508, CEP 70910-970 Brasília, DF, Brazil. E-mail: cicerocf@unb.br
\end{abstract}

\begin{abstract}
The objective of this work was to evaluate the effects of soil management systems, cover crops, and phosphate fertilization on soil humic fractions in a long-term experiment. The treatments consisted of conventional tillage and no-tillage with pearl millet (Pennisetum glaucum) or velvet bean (Mucuna aterrima) as cover crops, at two doses of phosphorous: 0 and $100 \mathrm{~kg} \mathrm{ha}^{-1} \mathrm{P}_{2} \mathrm{O}_{5}$ per year. Soil samples were taken 11 years after the establishment of the experiment and analyzed for soil total organic carbon and carbon content of humic fractions at $0.00-0.05,0.05-0.10$, and $0.10-0.20-\mathrm{m}$ depths. The humic fractions are sensitive to soil management, except free fulvic acid, which was the only one that did not reduce its carbon contents on the surface layer $(0.00-0.05 \mathrm{~m})$ with conventional tillage. The main changes occurred on the soil surface layer, in which the no-tillage system with pearl millet as a cover crop provided the highest carbon levels in humic fractions. Long-term phosphate fertilization under no-tillage, with pearl millet as a cover crop, promotes the accumulation of organic carbon in soil humic fractions.
\end{abstract}

Index terms: humic fractions, no-tillage, organic matter fractions, phosphate fertilization, soil fertility, soil quality.

\section{Matéria orgânica do solo influenciada por sistemas de manejo, adubação fosfatada e plantas de cobertura}

\begin{abstract}
Resumo - O objetivo deste trabalho foi avaliar os efeitos de sistemas de manejo do solo, de plantas de cobertura e da fertilização fosfatada nas frações húmicas do solo, em experimento de longa duração. Os tratamentos consistiram de sistemas de preparo convencional e de plantio direto com milheto (Pennisetum glaucum) ou com mucuna-preta (Mucuna aterrima) como planta de cobertura, sob duas doses de fósforo: 0 e $100 \mathrm{~kg} \mathrm{ha}^{-1} \mathrm{de}$ $\mathrm{P}_{2} \mathrm{O}_{5}$ por ano. As amostras de solo foram coletadas após 11 anos da implantação do experimento e analisadas quanto aos teores de carbono orgânico total e de carbono das frações humificadas no solo, nas camadas de $0,00-0,05,0,05-0,10$ e $0,10-0,20 \mathrm{~m}$ de profundidade. As frações humificadas são sensíveis ao manejo do solo, exceto o ácido fúlvico livre, que foi a única que não diminuiu seus conteúdos de carbono na camada superficial do solo $(0,00-0,05 \mathrm{~cm})$ com o plantio convencional. As principais alterações ocorreram na camada superficial, em que o plantio direto com milheto como planta de cobertura promoveu os maiores teores de carbono nas frações húmicas. A fertilização fosfatada por longo tempo sob plantio direto, com milheto como planta de cobertura, promove o acúmulo de carbono orgânico nas frações húmicas do solo.
\end{abstract}

Termos para indexação: frações húmicas, plantio direto, frações da matéria orgânica, fertilização fosfatada, fertilidade do solo, qualidade do solo.

\section{Introduction}

The use of technology is a key factor for obtaining high yields in Cerrado (Brazilian savanna) soils and also for preserving soil quality, by protecting soil organic matter (SOM) contents.

Over the past three decades, the Cerrado region has been increasingly adopting advanced technologies that include conservational tillage systems combined with the use of cover crops (Carvalho et al., 2012). Of these systems, the main and most comprehensive one is no-tillage, which provides several advantages that increase yield and reduce the impacts of farming on the environment (Ramos et al., 2013; Sá et al., 2015). Typically, organic matter is the soil component that is most affected by the use of the no-tillage system (Nunes et al., 2011; Guareschi et al., 2012; Gazolla et al., 2015; Sá et al., 2015). Therefore, SOM plays an important role in evaluating the changes promoted by the use of no-tillage combined or not with other technologies, such as cover crops and phosphate fertilization. 
However, due to the complexity of SOM, its different fractions should be studied separately for a better understanding of its dynamics. Humic fractions are highly resistant to biodegradation because of their inherent recalcitrance and interaction with soil mineral colloids, forming stable clay-humic complexes (Grinhut et al., 2007). This characteristic provides a long-term organic carbon compartment (West \& Post, 2002). Therefore, the study of humic fractions can enhance the effectiveness of the assessment of the impacts of conventional and conservational management systems, crop arrangements, and mineral fertilization on SOM preservation (Guimarães et al., 2013).

Despite their stability, humic fractions can be changed according to soil management, and different soil fractions can be used as indicators of SOM quality (Fontana et al., 2011b; Caetano et al., 2013). Higher levels of these fractions are generally observed in soil managements that do not involve soil disturbance, such as no-tillage (Liaudanskiene et al., 2013; Sá et al., 2015), as well as in soil management systems characterized by massive deposition of various plant residues (Arlauskiene et al., 2010).

In addition to the role played by the humic fractions of organic matter on soil fertility, studies have shown that higher levels of stable SOM contribute significantly to reduce $\mathrm{CO}_{2}$ emissions (Kragt et al., 2012), since the percentage of humic fractions in SOM indicates soil structural stability (Grinhut et al., 2007).

Although there are numerous studies on humification of SOM (Fontana et al., 2010, 2011a; Caetano et al., 2013; Campos et al., 2013; Santos et al., 2014), its use as an indicator of changes in SOM quality by longterm soil management systems and by the use of cover crops and phosphate fertilization are still limited for the Cerrado region.

The objective of this work was to evaluate the effects of soil management systems, cover crops, and phosphate fertilization on soil humic fractions in a long-term experiment.

\section{Materials and Methods}

The study was carried out in the experimental area of Embrapa Cerrados, in Planaltina, Brasília, DF, Brazil $\left(15^{\circ} 36^{\prime} \mathrm{S}, 47^{\circ} 42^{\prime} \mathrm{W}\right.$, at 1,014-m altitude). The climate is Cwa according to Köppen, with mean annual temperature of $21.3^{\circ} \mathrm{C}$ and precipitation of $1,570 \mathrm{~mm}$. The experiment was established in a
Latossolo Vermelho distrófico, i.e., an Oxisol, with a gently undulating relief ( $3 \%$ slope) and $571 \mathrm{~g} \mathrm{~kg}^{-1}$ clay, $72 \mathrm{~g} \mathrm{~kg}^{-1}$ silt, and $357 \mathrm{~g} \mathrm{~kg}^{-1}$ sand.

The area was deforested in 1976 and used for pasture and grain production over 20 years. In 1996, prior to soybean (Glycine max L.) sowing, lime was applied in the area for grain production. In the same agricultural year and in the following one (1997/1998), the area was cultivated with soybean with the application of 80 $\mathrm{kg} \mathrm{ha}^{-1} \mathrm{P}_{2} \mathrm{O}_{5}$ in the planting furrow, $80 \mathrm{~kg} \mathrm{ha}^{-1} \mathrm{~K}_{2} \mathrm{O}$ as $\mathrm{KCl}$, and $30 \mathrm{~kg} \mathrm{ha}^{-1}$ sulfur as gypsum, broadcasted on the soil surface. In 1998/1999, corn was grown in the area and $80 \mathrm{~kg} \mathrm{ha}^{-1} \mathrm{~K}_{2} \mathrm{O}, 30 \mathrm{~kg} \mathrm{ha}^{-1} \mathrm{~S}$, and $150 \mathrm{~kg} \mathrm{ha}^{-1}$ $\mathrm{N}$ as urea were applied at corn (Zea mays L.) planting, without phosphate fertilization. These three cultivation cycles were cropped in order to provide knowledge on area variability for selecting the experimental design and to achieve a state of high fertility for studying $\mathrm{P}$ management under this condition.

The experimentation actually began in the 1999/2000 season, with appropriate chemical soil conditions, using corn-soybean succession, with winter cover crops sown at the end of the rainy season and mowed at the flowering stage. Fertilizations with N, K, and S were equal to those in the three previous years, and the treatments with $\mathrm{P}$ doses were established. In 2008 and 2009 , the cover crops were fertilized with $45 \mathrm{~kg} \mathrm{ha}^{-1} \mathrm{~N}$ as urea, in order to increase plant biomass production.

Because of the common mid-summer drought phenomenon in the region ("veranico"), soybean and corn crops received supplemental sprinkler irrigation during drought occurrences in the rainy season. Irrigation was based on tensiometers installed in the plots at $0.20-\mathrm{m}$ depth, when soil water tension reached $45 \mathrm{kPa}$. The cover crops were also irrigated in winter with abundant water.

A randomized complete block design with splitplots was used. Management systems were randomly assigned to the plots, and $\mathrm{P}$ doses to the subplots. The treatments consisted of three management systems: CTm, conventional tillage system, with plowing and harrowing before planting, with pearl millet [Pennisetum glaucum (L.) R.Br.] as cover crop; NTm, no-tillage system, with pearl millet coverage; and NTv, no-tillage with velvet bean (Mucuna aterrima Merr.) as cover crop. Phosphate fertilization treatments consisted of 0 and $100 \mathrm{~kg} \mathrm{ha}^{-1} \mathrm{P}_{2} \mathrm{O}_{5}$ per year, applied as granular triple superphosphate in the planting furrow. 
Soil samples were taken in March 2010, during the seed filling of soybean, at $0.00-0.05,0.05-0.10$, and $0.10-0.20-\mathrm{m}$ soil depths, using an auger with $0.05-\mathrm{m}$ diameter. One composite sample was taken per plot, formed by 20 subsamples, i.e., four locations within each plot $\mathrm{x}$ five subsamples per location: one on the line and four on the equidistant inter-row spaces. The soil was homogenized and separated for chemical analyses, after air-drying and sieving to 2.0 or $0.5 \mathrm{~mm}$.

Soil samples at the same depths were also taken under native Cerrado vegetation close to the experiment, and used as a reference condition. These samples were taken at 20 random points, in two different places, that is, with two replicates.

Organic carbon (OC) was determined by wet oxidation with potassium dichromate $(10 \mathrm{~mL}$ of $0.167 \mathrm{~mol} \mathrm{~L}^{-1} \quad \mathrm{~K}_{2} \mathrm{Cr}_{2} \mathrm{O}_{7}$ ) in sulfuric acid medium $\left(20 \mathrm{mLH}_{2} \mathrm{SO}_{4}\right)$, withoutan external heat source, followed by titration with $0.4 \mathrm{~mol} \mathrm{~L}-1 \mathrm{Fe}\left(\mathrm{NH}_{4}\right)_{2}\left(\mathrm{SO}_{4}\right)_{2} \cdot 6 \mathrm{H}_{2} \mathrm{O}$ (Walkley \& Black, 1934).

Organic matter fractionation was performed by differential solubility in acidic and alkaline mediums, according to Dabin (1976) and Benites et al. (2003). Firstly, soil samples were subjected to a pre-treatment with $40 \mathrm{~mL}$ of orthophosphoric acid solution $2 \mathrm{~mol} \mathrm{~L}^{-1}$, in order to separate the light organic matter fraction through density and to solubilize the free fulvic acid (FFA) fraction; the filtered extract corresponded to FFA (Dabin, 1976).

After the separation of this fraction, the solid residue retained in the centrifuge tube was subjected to extraction of the other fractions: fulvic acid (FA), humic acid (HA), and humin (HU), by stirring with $20 \mathrm{~mL} \mathrm{NaOH}$ $0.1 \mathrm{~mol} \mathrm{~L}^{-1}$, according to Benites et al. (2003). The $\mathrm{pH}$ value of the alkaline extract (supernatant) was adjusted to 1.0-1.5, with $\mathrm{H}_{2} \mathrm{SO}_{4} 20 \%$, in order to separate humic and fulvic acids. The supernatant corresponding to FA was transferred to another centrifuge tube and its volume was completed to $50 \mathrm{~mL}$ distilled water. Then, $30 \mathrm{~mL} \mathrm{NaOH} 0.1 \mathrm{~mol} \mathrm{~L}^{-1}$ were used in the precipitate, corresponding to HA, which was then homogenized, and the volume was completed to $50 \mathrm{~mL}$ distilled water. Unlike in Benites et al. (2003), in the present study, the insoluble residue retained in the centrifuge tubes was considered as being the humin fraction, following the procedure described by Fontana et al. (2011b) and Gazolla et al. (2015). This fraction was heated in an oven up to $45^{\circ} \mathrm{C}$, until complete drying.
Carbon levels were determined in the extracts of the fractions: FFA, FA, HA, and HU. This was performed by carbon oxidation with potassium dichromate and titration with ferrous ammonium sulfate, with heating under reflux. The HA/FA ratio, an indicator of the quality of organic matter, was also obtained.

In the present study, a model with repeated measures was used, due to the importance of understanding the effect of depth in conventional and no-tillage systems and to overcome sample dependency between layers (Vivaldi, 1999). For this purpose, the restricted maximum likelihood model (REML), using Proc Mixed of SAS, version 9.1 (SAS Institute Inc., Cary, $\mathrm{NC}, \mathrm{USA}$ ), was considered in the analysis of variance (Anova) of the levels of OC, FFA, FA, HA, and HU, with the following model: $Y_{i j k}=\mu+B_{j}+S_{i}+\varepsilon_{i j}+D_{k}$ $+(\mathrm{SD})_{\mathrm{ik}}+\mathrm{d}_{\mathrm{l}}+(\mathrm{dS})_{\mathrm{il}}+\mathrm{dD}_{\mathrm{kl}}+\mathrm{dSD}_{\mathrm{ikl}}+\varepsilon_{\mathrm{ijkl}}$, in which $\mu$ is the overall data mean; $B$ is the block $(j=1,2$, $3)$; $\mathrm{S}$ is the management system $(\mathrm{i}=1,2)$; $\mathrm{D}$ is the $\mathrm{P}$ dose $(\mathrm{k}=1,2)$; $\mathrm{d}$ is soil depth $(1=1,2,3)$; and $\varepsilon$ is the experimental error.

When Anova was significant, Student's test was used to compare the means at $5 \%$ probability.

\section{Results and Discussion}

A summary of Anova is shown in Table 1. Under notillage system (NT), the distribution of OC followed a gradient, according to soil layers, at both doses of P. Greater OC levels were found in the top layer, decreasing with depth. This result contrasted with that of the conventional tillage system (CT), which did not show stratification of OC at the dose of $100 \mathrm{~kg} \mathrm{ha}^{-1}$ per year (P1) (Table 2). Guareschi et al. (2012) also

Table 1. Significance values of the effects of management system, phosphorous dose, soil depth, and their interactions on soil organic carbon and humic fractions ${ }^{(1)}$.

\begin{tabular}{lrrrrr}
\hline Source of variation & TOC & \multicolumn{4}{c}{ Humic substance } \\
\cline { 3 - 6 } & & \multicolumn{1}{c}{ FFA } & \multicolumn{1}{c}{ FA } & \multicolumn{1}{c}{ HA } & \multicolumn{1}{c}{ HU } \\
\hline System & $<0.0001$ & 0.5200 & 0.0865 & 0.0293 & 0.0085 \\
Dose & $<0.0001$ & 0.7470 & 0.3555 & $<0.0001$ & 0.5616 \\
System x dose & 0.5214 & 0.4479 & 0.1485 & 0.4499 & 0.0063 \\
Depth & $<0.0001$ & $<0.0001$ & $<0.0001$ & $<0.0001$ & $<0.0001$ \\
System x depth & $<0.0001$ & 0.0511 & 0.0006 & $<0.0001$ & $<0.0001$ \\
Dose x depth & 0.0028 & 0.3247 & 0.0154 & 0.0216 & 0.0004 \\
System x dose x depth & 0.0337 & 0.0793 & 0.5344 & 0.1341 & 0.0568 \\
\hline
\end{tabular}

${ }^{(1)} \mathrm{TOC}$, total organic carbon; FFA, free fulvic acid; FA, fulvic acid; HA, humic acid; and $\mathrm{HU}$, humin. 
reported stratification of OC levels with depth, under NT, with higher levels in the upper layers than CT.

Minimum soil disturbance, virtual absence of mechanical incorporation of organic waste into soil layers, and pronounced growth of roots in soil upper layers contribute to the gradient formation of $\mathrm{OC}$ levels (Bordin et al., 2008). However, conversion of natural vegetation into agroecosystems via ploughing degrades soil quality, and the mixing of the topsoil with the subsurface decreases organic matter stratification in CT (Franzluebbers, 2002).

The stratification of $\mathrm{C}$ in the soil upper profile plays an important role in soil quality, since stresses related to the application of pesticides, fertilizers, and to machinery traffic directly affect soil surface (Tormena et al., 2004), and greater concentrations of OC in the upper layers at NT allow greater stability of the porous system, mitigating the effects of soil compaction (Franzluebbers, 2002).

Regardless of the management system, phosphate fertilization and soil depth, humic fractions accounted for $80 \%$ total organic carbon (TOC). Among the fractions, HU accounted for $32 \%$ TOC, whereas the other fractions - FFA, FA, and HA - accounted for, in average, 11,24 , and $13 \%$ TOC.

The levels of $\mathrm{C}$ in humic fractions were affected by management systems and $\mathrm{P}$ doses, with significant double interactions, that is, system vs. depth, and dose vs. depth (Table 1). Carbon levels in the FFA fraction ranged from 1.65 to $2.00 \mathrm{~g} \mathrm{~kg}^{-1}$ (Figure 1) and, in FA, from 3.11 to $4.97 \mathrm{~g} \mathrm{~kg}^{-1}$ (Figure 2). The highest levels of FFA were found in deeper layers $(0.05-0.10$ and 0.10 $0.20 \mathrm{~m}$ ) in NT, since this fraction has higher mobility and is not associated with mineral material (Guerra \& Santos, 2008). These fractions are the most labile humic substances because of their lower molecular weight and higher density of carboxylic groups, compared to other fractions, such as HA and HU. Therefore, they show greater mobility in soil, which favors accumulation in deeper soil layers (Canellas et al., 2003).

The FA fraction showed the highest contents in the NTm and NTv systems, but with stratified distribution between the soil layers, with higher contents in the surface layers. Both FFA and FA fractions were more evenly distributed between the soil depths in NT. Moreover, CT showed lower FA contents than the other systems. This more even distribution in the soil upper profile, along with the lower content of FA in $\mathrm{CT}$, can be explained by the greater soil disturbance in this system, which becomes more susceptible to decomposition (Sá et al., 2015).

Several studies reported higher levels of $\mathrm{C}$ in the FA fraction in deeper soil layers (Passos et al., 2007; Fontana et al., 2011b; Caetano et al., 2013). However, in the present study, this mobility under NT was not so pronounced, possibly because the sampling depth was limited to $0.20 \mathrm{~m}$. Soil management may also have contributed to the lower FA levels under CT, suggesting that this fraction moved to greater depths or that it was transformed into HA.

The levels of HA ranged from 1.1 to $4.6 \mathrm{~g} \mathrm{~kg}^{-1}$ (Figure 2) and corroborate data from Pessoa et al. (2012). The distribution of this fraction in the soil was similar to that of FA, with levels decreasing in deeper soil layers under NT compared to CT. The HA fraction reduced $65 \%$, in average, from the $0.00-0.05$ to the $0.10-0.20-\mathrm{m}$ layer. As for the FA fraction, this decrease was $25 \%$, indicating that this fraction had greater mobility through the soil profile in comparison to HA. Santos et al. (2013) also observed that the levels of fulvic and humic acids decreased in deeper soil layers due to the decreased presence of crop residues, confirming the findings of the present study.

Benites et al. (2003) highlighted that the alkalineinsoluble residue, mainly because of the presence of non-humic materials, does not represent the $\mathrm{HU}$

Table 2. Total organic carbon in different soil layers of an Oxisol cultivated for 11 years under different soil management systems, cover crops - velvet bean (Mucuna aterrima) or pearl millet (Pennisetum glaucum) -, and phosphorus doses ${ }^{(1)}$.

\begin{tabular}{|c|c|c|c|c|c|c|}
\hline \multirow{2}{*}{$\begin{array}{l}\text { Depth } \\
\text { (m) }\end{array}$} & \multicolumn{2}{|c|}{ NT velvet bean } & \multicolumn{2}{|c|}{ NT pearl millet } & \multicolumn{2}{|c|}{ CT pearl millet } \\
\hline & $\mathrm{P} 0$ & $\mathrm{P} 1$ & P0 & $\mathrm{P} 1$ & P0 & $\mathrm{P} 1$ \\
\hline $0.00-0.05$ & $18.98 \mathrm{Ca}$ & $22.13 \mathrm{Ba}$ & $20.74 \mathrm{Ba}$ & $24.28 \mathrm{Aa}$ & $15.72 \mathrm{Da}$ & $16.48 \mathrm{Da}$ \\
\hline $0.05-0.10$ & $16.75 \mathrm{ABb}$ & $16.29 \mathrm{BCb}$ & $17.65 \mathrm{ABb}$ & $18.23 \mathrm{Ab}$ & $14.91 \mathrm{Cab}$ & $16.51 \mathrm{Ba}$ \\
\hline $0.10-0.20$ & $13.46 \mathrm{Bc}$ & $12.98 \mathrm{Bc}$ & $14.09 \mathrm{Abc}$ & $14.37 \mathrm{Abc}$ & $13.93 \mathrm{ABb}$ & $15.05 \mathrm{Aa}$ \\
\hline
\end{tabular}

${ }^{(1)}$ Means followed by equal letters, uppercase in the lines and lowercase in the columns, do not differ by Student's test, at $5 \%$ probability ( $\mathrm{n}=3$ ). NT, no-tillage system; CT, conventional tillage system; $\mathrm{P} 0,0.0 \mathrm{~kg} \mathrm{ha}^{-1} \mathrm{P}_{2} \mathrm{O}_{5}$ per year; and $\mathrm{P} 1,100 \mathrm{~kg} \mathrm{ha}^{-1} \mathrm{P}_{2} \mathrm{O}_{5}$ per year, as triple superphosphate applied in the planting furrow. 
fraction. However, in the present work, the HU fraction was considered as all the insoluble residue in the alkali solution during the classical fractionation of humic substances, as in Fontana et al. (2011b) and Gazolla et al. (2015).

The HU fraction also had a similar distribution, with differences between management systems and cover crops only in the surface layer, following the pattern $\mathrm{NTm}>\mathrm{NTv}>\mathrm{CTm}$ (Figure 2). In NT, cover crops provided different contents of $\mathrm{HU}$, with higher levels in NTm. This was also observed for HA, in the surface layer. The greater amount of biomass input by the grass, when compared to velvet bean, can explain this result, which was also observed by Nunes et al. (2011) in the same experiment. Arlauskiene et al. (2010) reported a significant increase in HA levels after the introduction of cover crops in the evaluated systems, with increasing tendency over the years. HU values were lower in CT compared to NT, indicating that even this more recalcitrant fraction is affected by soil management (Fontana et al., 2011b).

Phosphate fertilization (P1) raised the levels of FA, HA, and HU (Figure 2). This increase was significant for FA and HU in the 0.00-0.05-m layer, and for HA in the first two layers. This can be attributed to the fact

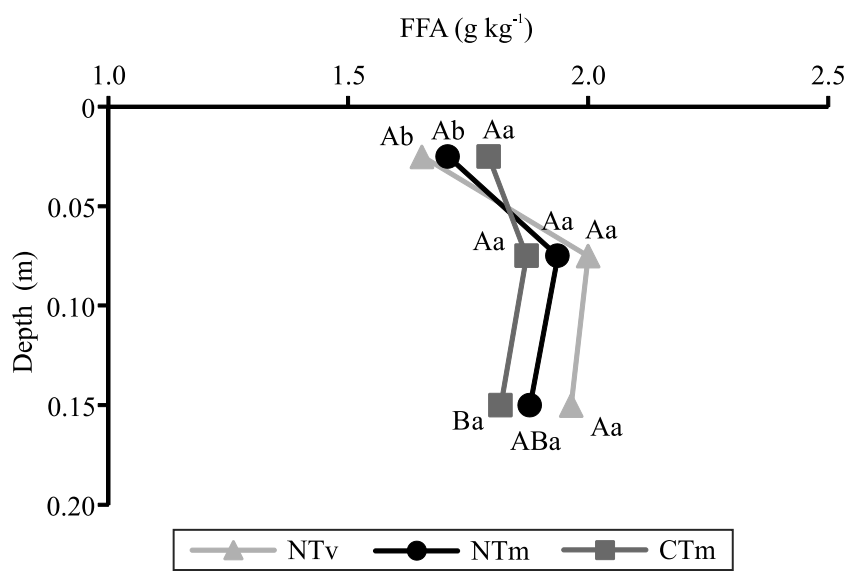

Figure 1. Distribution of the free fulvic acid (FFA) fraction at different soil depths of an Oxisol cultivated for 11 years under different soil management systems: NTv, no-tillage + velvet bean (Mucuna aterrima) as a cover crop; NTm, notillage + pearl millet (Pennisetum glaucum) as a cover crop; and CTm, conventional tillage + pearl millet as a cover crop. Means followed by equal letters, lowercase for depths and uppercase for systems at the same depth, do not differ by Student's test, at 5\% probability. that phosphate fertilization in soil management systems tends to increase the amount of dry matter added to the surface layers, favoring continuous decomposition (Fontana et al., 2001). Furthermore, P is exported by the crops with harvest and, since it is not restored in the absence of $\mathrm{P}$ fertilization, the nutrient is depleted in the soil, resulting in lower grain yield and higher accumulation of biomass in the soil (Nunes et al., 2011).

The HU fraction showed the highest levels in all soil management systems, representing the major form of carbon accumulation in the soil. The levels of $\mathrm{HU}$ ranged from 4 to $8 \mathrm{~g} \mathrm{~kg}^{-1}$ (Figure 2), in alignment with the findings of Barreto et al. (2008) and Caetano et al. (2013), with an average of 32\% TOC (Table 3). This predominance of the HU fraction is related to its insolubility and resistance to biodegradation, which is favored by the formation of stable clayhumic complexes (Fontana et al., 2011b). The lower percentages of FFA in soil OC indicate that the enhanced addition of $\mathrm{OC}$ by the cover crops favored the continuous decomposition of SOM, along with this easily biodegradable fraction, as reported by Fontana et al. (2001).

The percentages of the less stable fractions, that is, FFA and FA, in soil OC increased in deeper layers, in all management systems and in the native environment, showing the greater mobility of these fractions (Table 3). In turn, the percentages of HA and $\mathrm{HU}$ in $\mathrm{OC}$ decreased in deeper layers, except for the more homogeneous percentage of $\mathrm{HU}$ in native Cerrado. The smaller percentage of HA in relation to FA in OC indicates a different formation dynamics of these acids, possibly due to the lower stabilization of SOM in the studied environments (Kleber et al., 2007) The resultant low HA/FA ratio, which ranged from 0.2 to 0.9 (mean 0.5 ), indicates a poorly stabilized organic matter (Table 4). In tropical soils, this ratio is usually less than 1, due to the lower intensity of humification processes, such as condensation and synthesis, and to the intense mineralization of residues (Cerri \& Volkoff, 1988).

The HA/FA ratio was higher in the surface layer and decreased in the deeper layers under NT. The greater biological activity in surface layers increases OC mineralization and the production of soluble phenolic compounds. Through polycondensation, these compounds generate the HA fraction (Duchaufour, 
1977). When $P$ was added to soil under NT, the ratio was similar to that observed in the natural Cerrado environment. In CT, it was lower in the $0.00-0.05-\mathrm{m}$ soil layer, for both $\mathrm{P}$ doses.

$\mathrm{FA}\left(\mathrm{g} \mathrm{kg}^{-1}\right)$

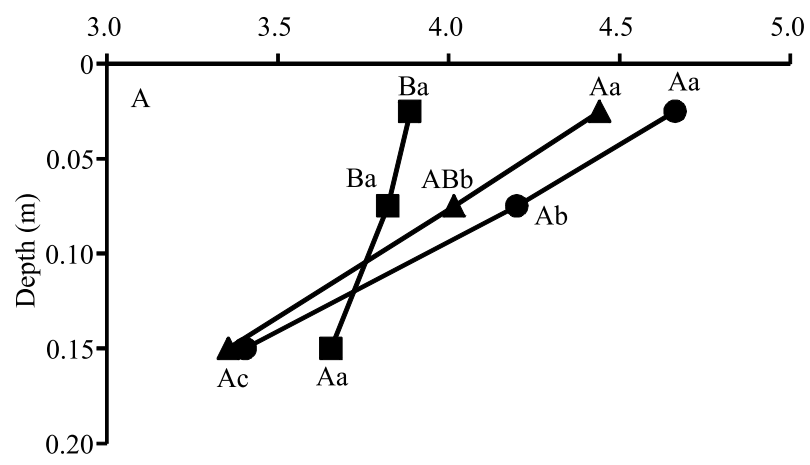

$\mathrm{HA}\left(\mathrm{g} \mathrm{kg}^{-1}\right)$

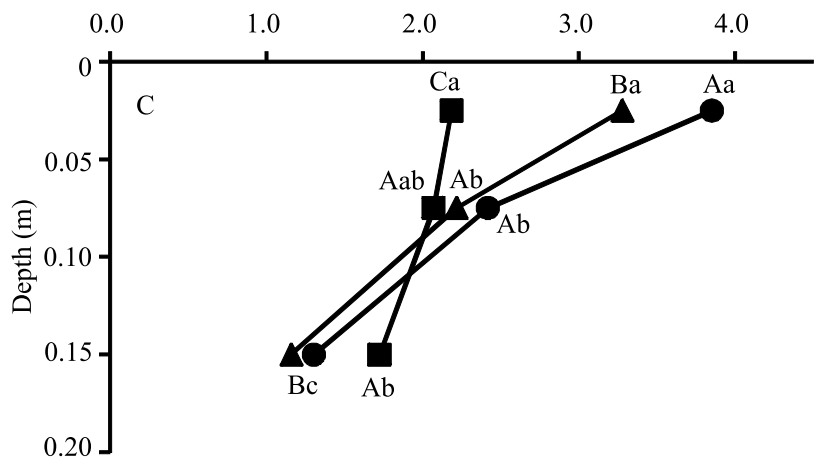

$\mathrm{HU}\left(\mathrm{g} \mathrm{kg}^{-1}\right)$
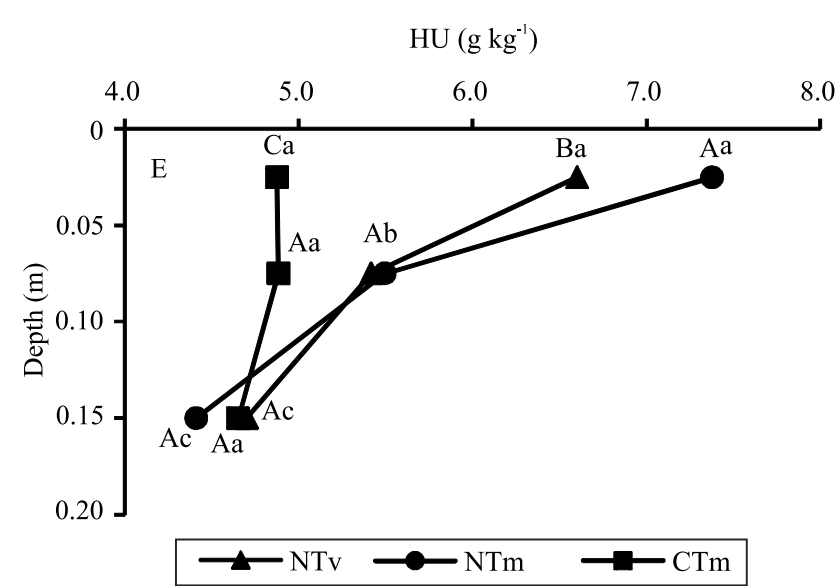

Humic fractions were lower in native Cerrado (Figure 3), despite being considered protected and stable forms of carbon. Increases in the HA fraction in the NTm and NTv systems were observed when
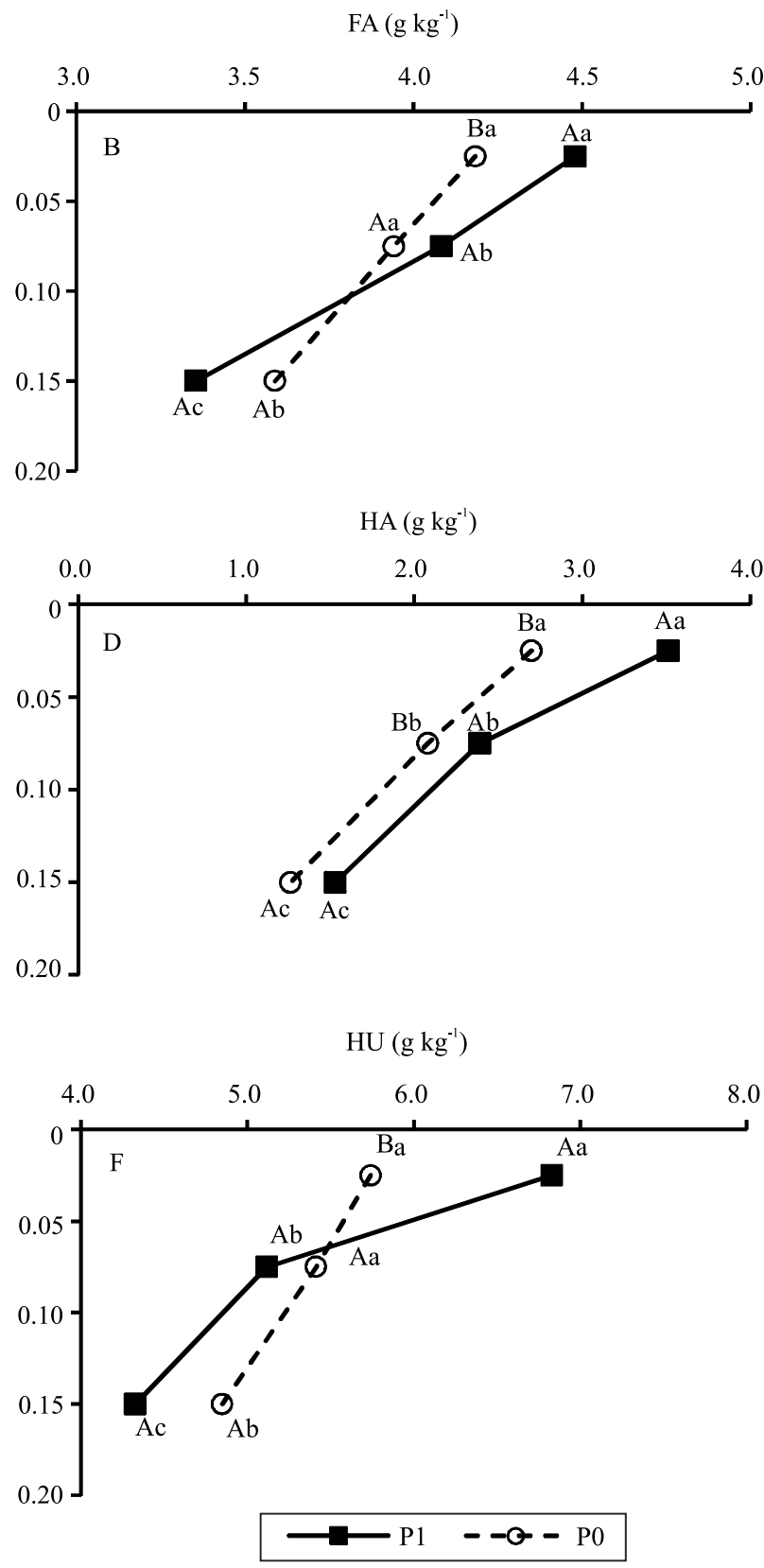

Figure 2. Distribution of the fulvic acid (FA), humic acid (HA), and humin (HU) fractions at different soil depths of an Oxisol cultivated for 11 years under different soil management systems and at different $P$ fertilization doses. Management systems: NTv, no-tillage + velvet bean (Mucuna aterrima) as cover crop; NTm, no-tillage + pearl millet (Pennisetum glaucum) as cover crop; and CTm, conventional tillage + pearl millet as cover crop. $\mathrm{P}$ fertilization doses: $\mathrm{P} 0,0.00 \mathrm{~kg}$ ha $\mathrm{P}_{2} \mathrm{O}_{5}$ per year; and $\mathrm{P} 1,100 \mathrm{~kg} \mathrm{ha}^{-1} \mathrm{P}_{2} \mathrm{O}_{5}$ per year, as triple superphosphate applied in the planting furrow. Means followed by equal letters, lowercase for depths and uppercase for systems at the same depth, do not differ by Student's test, at 5\% probability. 
Table 3. Carbon in soil humic fractions in relation to total organic carbon (TOC) at different soil depths of an Oxisol cultivated for 11 years under different soil management systems and cover crops - velvet bean (Mucuna aterrima) or pearl millet (Pennisetum glaucum) -, at the P fertilization dose of $100 \mathrm{~kg}$ ha per year $\mathrm{P}_{2} \mathrm{O}_{5}{ }^{(1)}$.

\begin{tabular}{|c|c|c|c|c|}
\hline System & $\begin{array}{l}\text { FFA/ } \\
\text { TOC }\end{array}$ & $\begin{array}{l}\text { FA/ } \\
\text { TOC }\end{array}$ & $\begin{array}{l}\text { HA/ } \\
\text { TOC }\end{array}$ & $\begin{array}{l}\mathrm{HU} / \\
\text { TOC }\end{array}$ \\
\hline & \multicolumn{4}{|c|}{$0.00-0.05 \mathrm{~m}$} \\
\hline No-tillage + velvet bean & 7 & 20 & 17 & 33 \\
\hline No-tillage + pearl millet & 7 & 21 & 18 & 35 \\
\hline Conventional tillage + pearl millet & 13 & 30 & 17 & 35 \\
\hline \multirow[t]{2}{*}{ Cerrado } & 10 & 18 & 14 & 38 \\
\hline & \multicolumn{4}{|c|}{$0.05-0.10 \mathrm{~m}$} \\
\hline No-tillage + velvet bean & 12 & 25 & 15 & 30 \\
\hline No-tillage + pearl millet & 10 & 24 & 14 & 31 \\
\hline Conventional tillage + pearl millet & 11 & 23 & 14 & 29 \\
\hline \multirow[t]{2}{*}{ Cerrado } & 13 & 23 & 11 & 36 \\
\hline & \multicolumn{4}{|c|}{$0.10-0.20 \mathrm{~m}$} \\
\hline No-tillage + velvet bean & 16 & 24 & 10 & 31 \\
\hline No-tillage + pearl millet & 13 & 23 & 10 & 31 \\
\hline Conventional tillage + pearl millet & 12 & 24 & 12 & 30 \\
\hline Cerrado & 14 & 23 & 8 & 36 \\
\hline
\end{tabular}

(1)FFA, free fulvic acid; FA, fulvic acid; HA, humic acid; and HU, humin. phosphate fertilization was used, in all soil layers. This increase shows the improvement in OC quality promoted by agriculture management systems, when compared to native Cerrado, since HA contents are directly correlated with parameters of fertility and quality of SOM (Canellas et al., 2003).

As for the $0.05-0.10 \mathrm{~m}$ layer, the HA fraction increased in all management systems, except in CT

Table 4. Values of the ratio between humic acid and fulvic acid (HA/FA) at different soil depths of an Oxisol cultivated for 11 years under different soil management systems, cover crops - velvet bean (Mucuna aterrima) or pearl millet (Pennisetum glaucum) -, and P fertilization levels ${ }^{(1)}$.

\begin{tabular}{cccccccccc}
\hline Depth (m) & \multicolumn{2}{c}{ NT velvet bean } & \multicolumn{2}{c}{ NT pearl millet } & & \multicolumn{3}{c}{ CT pearl millet } & Cerrado \\
\cline { 2 - 3 } & P0 & P1 & & P0 & P1 & & P0 & P1 & \\
\hline $0.00-0.05$ & 0.6 & 0.8 & 0.7 & 0.9 & & 0.5 & 0.6 & 0.8 \\
$0.05-0.10$ & 0.5 & 0.6 & & 0.6 & 0.6 & & 0.5 & 0.6 & 0.5 \\
$0.10-0.20$ & 0.3 & 0.4 & 0.3 & 0.4 & 0.4 & 0.5 & 0.4 \\
\hline
\end{tabular}

${ }^{(1)} \mathrm{NT}$, no-tillage system; CT, conventional tillage system; $\mathrm{P} 0,0.00 \mathrm{~kg} \mathrm{ha}^{-1}$ per year $\mathrm{P}_{2} \mathrm{O}_{5}$; and $\mathrm{P} 1,100 \mathrm{~kg} \mathrm{ha}^{-1}$ per year $\mathrm{P}_{2} \mathrm{O}_{5}$, as triple superphosphate applied in the planting furrow.
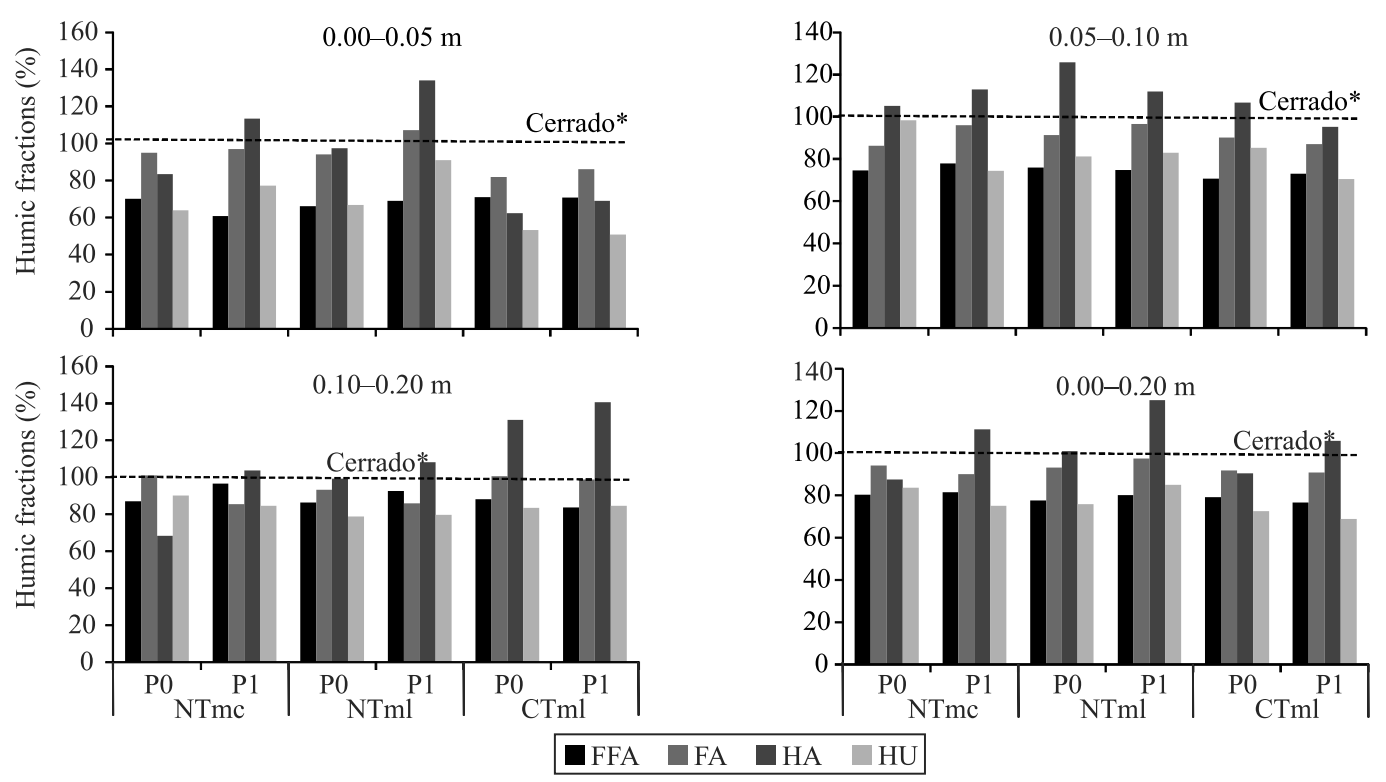

Figure 3. Percentage of humic fractions under different soil management systems: NTv, no-tillage + velvet bean (Mucuna aterrima) as a cover crop; NTm, no-tillage + pearl millet (Pennisetum glaucum) as cover crop; and CTm, conventional tillage + pearl millet as cover crop, at different $\mathrm{P}$ fertilization doses $\left(\mathrm{P} 0,0.00 \mathrm{~kg} \mathrm{ha}^{-1} \mathrm{P}_{2} \mathrm{O}_{5}\right.$ per year; and $\mathrm{P} 1,100 \mathrm{~kg} \mathrm{ha}^{-1} \mathrm{P}_{2} \mathrm{O}_{5}$ per year, as triple superphosphate applied in the planting furrow), compared to native Cerrado vegetation at $0.00-0.05,0.05-0.10$, 0.10-0.20, and 0.00-0.20-m soil depths (weighted average). FFA, free fulvic acid; FA, fulvic acid; HA, humic acid; and HU, humin. *Absolute values of FFA, FA, HA, and HU in Cerrado soil at the following layers: $0.00-0.05 \mathrm{~m}, 2.53,4.63,3.33$, and $9.35 \mathrm{~g} \mathrm{~kg}^{-1}$, respectively; $0.05-0.10 \mathrm{~m}, 2.60,4.44,2.01$, and $6.53 \mathrm{~g} \mathrm{~kg}^{-1} ; 0.10-0.20 \mathrm{~m}, 2.12,3.71,1.26$, and $5.55 \mathrm{~g} \mathrm{~kg}^{-1}$; and $0.00-0.20 \mathrm{~m}, 2.34,4.11,1.96$, and $6.74 \mathrm{~g} \mathrm{~kg}^{-1}$. 
with phosphate fertilization (Figure 3). In general, higher values were observed with the application of $100 \mathrm{~kg} \mathrm{ha}^{-1} \mathrm{P}_{2} \mathrm{O}_{5}$ per year. This reinforces the idea that the use of fertilizers, crop rotation, and cover crops is related to higher concentrations of biomass in soil surface layers, and, therefore, to higher levels of $\mathrm{C}$ in humic fractions, contributing to a more stable ecosystem.

\section{Conclusions}

1. The no-tillage system tends to promote the stratification of soil organic carbon and of humic substances according to soil depth, whereas conventional tillage promotes a more even distribution of total carbon within soil layers.

2. The main changes in organic carbon levels occur in the surface soil layer $(0.00-0.05 \mathrm{~m})$, in which the notillage system with pearl millet (Pennisetum glaucum) as cover crop provides the highest carbon levels in the humic fractions.

3. The use of phosphate fertilization, for 11 years under no-tillage, using pearl millet as a cover crop, promotes the accumulation of organic carbon in soil humic fractions.

\section{References}

ARLAUSKIENE, A.; MAIKSTENIENE, S.; SLEPETIENE, A. Effect of cover crops and straw on the humic substances in the clay loam Cambisol. Agronomy Research, v.8, p.397-402, 2010.

BARRETO, A.C.; FREIRE, M.B.G. dos S.; NACIF, P.G.S.; ARAÚJO, Q.R.; FREIRE, F.J.; INÁCIO, E. dos S.B. Fracionamento químico e físico do carbono orgânico total em um solo de mata submetido a diferentes usos. Revista Brasileira de Ciência do Solo, v.32, p.1471-1478, 2008. DOI: 10.1590/S010006832008000400011.

BENITES, V.M.; MADARI, B.; MACHADO, P.L.O. de A. Extração e fracionamento quantitativo de substâncias húmicas do solo: um procedimento simplificado de baixo custo. Rio de Janeiro: Embrapa Solos, 2003. 7p. (Embrapa Solos. Comunicado técnico, 16).

BORDIN, I.; NEVES, C.S.V.J.; MEDINA, C. de C.; SANTOS, J.C.F. dos; TORRES, E.; URQUIGA, S. Matéria seca, carbono e nitrogênio de raízes de soja e milho em plantio direto e convencional. Pesquisa Agropecuária Brasileira, v.43, p.17851792, 2008. DOI: 10.1590/S0100-204X2008001200020.

CAETANO, J.O.; BENITES, V. de M.; SILVA, G.P.; SILVA, I.R. da; ASSIS, R.L. de; CARGNELUTTI FILHO, A. Dinâmica da matéria orgânica de um Neossolo Quartzarênico de Cerrado convertido para cultivo em sucessão de soja e milheto. Revista
Brasileira de Ciência do Solo, v.37, p.1245-55, 2013. DOI: 10.1590/S0100-06832013000500014.

CAMPOS, L.P.; LEITE, L.F.C.; MACIEL, G.A.; BRASIL, E.L.; IWATA, B. de F. Estoques e frações de carbono orgânico em Latossolo Amarelo submetido a diferentes sistemas de manejo. Pesquisa Agropecuária Brasileira, v.48, p.304-312, 2013. DOI: 10.1590/S0100-204X2013000300009.

CANELLAS, L.P.; VELLOSO, A.C.X.; MARCIANO, C.R.; RAMALHO, J.F.G.P.; RUMJANEK, V.M.; REZENDE, C.E.; SANTOS, G.A. Propriedades químicas de um Cambissolo cultivado com cana-de-açúcar, com preservação do palhiço e adição de vinhaça por longo tempo. Revista Brasileira de Ciência do Solo, v.27, p.935-944, 2003. DOI: 10.1590/S0100-06832003000500018.

CARVALHO, A.M. de; COELHO, M.C.; DANTAS, R.A.; FONSECA, O.P.; GUIMARÃES JÚNIOR, R.; FIGUEIREDO, C.C. Chemical composition of cover plants and its effect on maize yield in no-till systems in the Brazilian savanna. Crop and Pasture Science, v.63, p.1075-1081, 2012. DOI: 10.1071/CP12272.

CERRI, C.C.; VOLKOFF, B. Matéria orgânica de três solos dos campos inundáveis da ilha do Marajó-PA. Revista Brasileira de Ciência do Solo, v.12, p.93-100, 1988.

DABIN, B. Méthode d'extraction et de fracctionnement des matières humique du sol: application à quelques études pédologiques et agronomiques dans les sols tropicaux. Service Pedologic, v.14, p.287-297, 1976.

DUCHAUFOUR, P. Pédologie: pédogenese et classification. Paris: Masson, 1977. v.1, 478p.

FONTANA, A.; PEREIRA, M.G.; ANJOS, L.H.C. dos; BENITES, V. de M. Classificação de horizontes diagnósticos em níveis hierárquicos inferiores com base nas frações húmicas. Revista Brasileira de Ciência do Solo, v.35, p.313-324, 2011a. DOI: 10.1590/S0100-06832011000200003.

FONTANA, A.; PEREIRA, M.G.; ANJOS, L.H.C. dos; BENITES, V. de M. Quantificação e utilização das frações húmicas como característica diferencial em horizontes diagnósticos de solos brasileiros. Revista Brasileira de Ciência do Solo, v.34, p.12411257, 2010. DOI: 10.1590/S0100-06832010000400023.

FONTANA, A.; PEREIRA, M.G.; NASCIMENTO, G.B. do; ANJOS, L.H.C. dos; EBELING, A.G. Matéria orgânica em solos de tabuleiros na região norte Fluminense-RJ. Floresta e Ambiente, v.8, p.114-119, 2001.

FONTANA, A.; SILVA, C.F. da; PEREIRA, M.G.; LOSS, A.; BRITO, R.J. de; BENITES, V. de M. Avaliação dos compartimentos da matéria orgânica em área de Mata Atlântica. Acta Scientiarum. Agronomy, v.33, p.545-550, 2011b. DOI: 10.4025/actasciagron. v33i3.5169.

FRANZLUEBBERS, A.J. Soil organic matter stratification ratio as an indicator of soil quality. Soil and Tillage Research, v.66, p.95106, 2002. DOI: 10.1016/S0167-1987(02)00018-1.

GAZOLLA, P.R.; GUARESCHI, R.F.; PERIN, A.; PEREIRA, M.G.; ROSSI, C.Q. Frações da matéria orgânica do solo sob pastagem, sistema plantio direto e integração lavoura-pecuária. Semina: Ciências Agrárias, v.36, p.693-704, 2015. DOI: 10.5433/1679-0359.2015v36n2p693. 
GRINHUT, T.; HADAR, Y.; CHEN, Y. Degradation and transformation of humic substances by saprotrophic fungi: processes and mechanisms. Fungal Biology Reviews, v.21, p.179189, 2007. DOI: 10.1016/j.fbr.2007.09.003.

GUARESCHI, R.F.; PEREIRA, M.G.; PERIN, A. Deposição de resíduos vegetais, matéria orgânica leve, estoques de carbono e nitrogênio e fósforo remanescente sob diferentes sistemas de manejo no cerrado goiano. Revista Brasileira de Ciência do Solo, v.36, p.909-920, 2012. DOI: 10.1590/S0100-06832012000300021.

GUERRA, J.G.M.; SANTOS, G. de A. Métodos químicos e físicos. In: SANTOS, G. de A.; SILVA, L.S. da; CANELLAS, L.P.; CAMARGO, F. de O. (Ed.). Fundamentos da matéria orgânica do solo: ecossistemas tropicais e subtropicais. 2.ed. rev. e atual. Porto Alegre: Metrópole, 2008. p.185-198.

GUIMARÃES, D.V.; GONZAGA, M.I.S.; SILVA, T.O. da; SILVA, T.L. da; DIAS, N. da S.; MATIAS, M.I.S. Soil organic matter pools and carbon fractions in soil under different land uses. Soil and Tillage Research, v.126, p.177-182, 2013. DOI: 10.1016/j. still.2012.07.010.

KLEBER, M.; SOLLINS, P.; SUTTON, R. A conceptual model of organo-mineral interactions in soils: self-assembly of organic molecular fragments into zonal structures on mineral surfaces. Biogeochemistry, v.85, p.9-24, 2007. DOI: 10.1007/s10533-0079103-5.

KRAGT, M.E.; PANNELL, D.J.; ROBERTSON, M.J.; THAMO, T. Assessing costs of soil carbon sequestration by crop-livestock farmers in Western Australia. Agricultural Systems, v.112, p.2737, 2012. DOI: 10.1016/j.agsy.2012.06.005.

LIAUDANSKIENE, I.; SLEPETIENE, A.; VELYKIS, A.; SATKUS, A. Distribution of organic carbon in humic and granulodensimetric fractions of soil as influenced by tillage and crop rotation. Estonian Journal of Ecology, v.62, p.53-69, 2013. DOI: 10.3176/eco.2013.1.05.

NUNES, R. de S.; LOPES, A.A. de C.; SOUSA, D.M.G. de; MENDES, I. de C. Sistemas de manejo e os estoques de carbono e nitrogênio em Latossolo de Cerrado com a sucessão soja-milho. Revista Brasileira de Ciência do Solo, v.35, p.1407-1419, 2011. DOI: 10.1590/S0100-06832011000400035.

PASSOS, R.R.; RUIZ, H.A.; MENDONÇA, E. de S.; CANTARUTTI, R.B.; SOUZA, A.P. de. Substâncias húmicas, atividade microbiana e carbono lábil em agregados de um Latossolo Vermelho distrófico sob duas coberturas. Revista Brasileira de Ciência do Solo, v.31, p.1119-1129, 2007. DOI: 10.1590/S010006832007000500027.
PESSOA, P.M. de A.; DUDA, G.P.; BARROS, R.B. de; FREIRE, M.B.G. dos S.; NASCIMENTO, C.W.A. do; CORREA, M.M. Frações de carbono orgânico de um Latossolo húmico sob diferentes usos no agreste brasileiro. Revista Brasileira de Ciência do Solo, v.36, p.97-104, 2012. DOI: 10.1590/S0100-06832012000100011.

RAMOS, D.D.; SILVA, E.F. da; ENSINAS, S.C.; SOUZA, N.H. de; POTRICH, D.C.; FREITAS, M.E. de; FORMAGIO, A.S.N.; VIEIRA, M. do C. Stocks of carbon, total nitrogen and humic substances in soil under different cropping systems. Semina: Ciências Agrárias, v.34, p.2219-28, 2013. DOI: 10.5433/1679-0359.2013v34n5p2219.

SÁ, J.C. de M.; SÉGUY, L.; TIVET, F.; LAL, R.; BOUZINAC, S.; BORSZOWSKEI, P.R.; BRIEDIS, C.; SANTOS, J.B. dos; CRUZ HARTMAN, D. da; BERTOLONI, C.G.; ROSA, J.; FRIEDRICH, T. Carbon depletion by plowing and its restoration by no-till cropping systems in Oxisols of subtropical and tropical agroecoregions in Brazil. Land Degradation and Development, v.26, p.531-543, 2015. DOI: 10.1002/ldr.2218.

SANTOS, D.C. dos; FARIAS, M. de O.; LIMA, C.L.R. de; KUNDE, R.J.; PILLON, C.N.; FLORES, C.A. Fracionamento químico e físico da matéria orgânica de um Argissolo Vermelho sob diferentes sistemas de uso. Ciência Rural, v.43, p.838-844, 2013. DOI: $10.1590 / \mathrm{S} 0103-84782013005000037$.

SANTOS, I.L. dos; CAIXETA, C.F.; SOUSA, A.A.T.C. de; FIGUEIREDO, C.C. de; RAMOS, M.L.G.; CARVALHO, A.M. de. Cover plants and mineral nitrogen: effects on organic matter fractions in an oxisol under no-till in the cerrado. Revista Brasileira de Ciência do Solo, v.38, p.1874-1881, 2014. DOI: 10.1590/S0100-06832014000600022.

TORMENA, C.A.; FRIEDRICH, R.; PINTRO, J.C.; COSTA, A.C.S.; FIDALSKI, J. Propriedades físicas e taxa de estratificação de carbono orgânico num Latossolo Vermelho após dez anos sob dois sistemas de manejo. Revista Brasileira de Ciência do Solo, v.28, p.1023-1031, 2004. DOI: 10.1590/S010006832004000600011 .

VIVALDI, L.J. Análise de experimentos com dados repetidos ao longo do tempo ou espaço. Planaltina: Embrapa-CPAC, 1999. 52p. (Embrapa-CPAC. Documentos, 8).

WALKLEY, A.; BLACK, J.A. An examination of the Degtjareff method for determining soil organic matter and a proposed modification of the chromic titration method. Soil Science, v.37, p.29-38, 1934. DOI: 10.1097/00010694-193401000-00003.

WEST, T.O; POST, W.M. Soil organic carbon sequestration rates by tillage and crop rotation. Soil Science Society of America Journal, v.66, p.1930-1946, 2002. DOI: 10.2136/sssaj2002.1930.

Received on June 24, 2015 and accepted on February 05, 2016

Pesq. agropec. bras., Brasília, v.51, n.9, p.1668-1676, set. 2016

DOI: 10.1590/S0100-204X2016000900067 